Vol. 3, No. 1, January 2020, page 275 - 281

ISSN 2614-1981 (Print)

ISSN 2615-0352 (Online)

Journal of Management and Business Aplication

\title{
STRATEGIC ROLE OF MOTIVATION AND LEADERSHIP IN IMPROVING TEACHER PERFORMANCE
}

\author{
Muhdar \\ Higher Education of Economic Mandala \\ E-mail: Yesmuhdar@gmail.com
}

\begin{abstract}
This study is aimed at analyzing the role of motivation and leadership strategies in improving the performance of case study teachers in teachers at SMK Negeri Kalibaru. The data uses primary data and obtained by interview and questionnaire distribution method with the population in this study were all Gorvernmentalteachers of SMK Negeri Kalibaru Banyuwangi with 38 people as respondents in this study. The analysis includes the instrument test that is the validity and reliability test, econometric evaluation or classic assumption test that is normality test, multicollinearity test and heteroscedasticity test, model suitability test and multiple regression analysis results are obtained: Motivation has a strategic and positive role on performance. Leadership has a strategic and positive role and is significant to performance. So from this conclusion, Motivation and Leadership have a strategic role in increasing teacher performance.From the results of the study, it is expected that schools and principals will pay more attention and improve services to teachers in motivating and leading teachers and providing positive behavior so that teachers can work well, responsible, comfortable and improve school goals in accordance with the vision and mission of the school.
\end{abstract}

Keywords: Motivation, Leadership, and Performance.

\section{INTRODUCTION}

The dense population of Indonesia needs to improve the quality of education and provision of skills for human resources starting from high school to University degree level. Education is important for anyone not only children but everyone also needs education.Education can be obtained at school and in other non-formal education organizations. Whatever education is taken is basically an effort to increase one's knowledge from not knowing to knowing and understanding.The quality of education is very depending on the educational program which is implemented. Not only that quality education can be obtained if the teaching staff can really carry out the education program well. So that our country is not inferior to neighboring countries, of course, the government must improve the quality of existing education. Education in Indonesia is still classified as middle-low because of inadequate systems and facilities.

Improving the quality of education is expected to improve teacher performance and innovation is always developed as 
stated by Rivai (2005: 14) performance itself is defined as the outcome or overall level of success of a person during a certain period to carry out the task compared with various possibilities, such as standard results work, targets or criteria that have been determined in advance andhave been mutually agreed upon.

As well as the statement from Mangkunegara, Anwar A (2006: 67), his statement that performance (work performance) is the work of quality and quantity achieved by an employee in carrying out their duties in accordance with the responsibilities given to him. Factors that affect the performance of one's teacher can come from within the individual itself such as motivation, skills, and also education. There are also factors from outside the individual such as work climate, salary level, etc. (Asf \& Mustofa, 2013: 160). According to Porter et al., Filak \& Sheldon (Rasheed et al, 2010), teacher work motivation is very important for the performance and success of any education system. According to Suryani Dewi Pratiwi's research (2013) that Motivation influences teacher performance and Principal Leadership according to teacher perceptions influences teacher performance.

Working motivation must get more serious attention because it can measure how much encouragement from inside and outside of school. Because low motivation also influences low productive behavior. Besides, the important thing is one's leadership is also expected to influence the performance of Govornment teachers of Vocational School in Kalibaru. Thus the problem that can be formulated is whether motivation and leadership can improve performance.

\section{RESEARCH METHODS}

This research was conducted inBanyuwangiKalibaru Vocational School, the time spent in this study was carried out in January to February 2020 on the effective hours of teaching and learning at
Kalibaru Vocational School.

This study only examined a portion of the population, so the study was called a sample study. According to Sugiyono (2010: 215) the sample is "a portion of the population". The population is for example residents in certain regions, the number of employees in certain organizations, the number of teachers and students in certain schools and so on. Meanwhile, Margono (2010: 121) argues that the sample is "as part of the population, for example (monsters) which is taken by using certain methods". Similarly, Sudjana (2005: 6) argues that the sample is "a portion is taken from the population". Based on some expert opinions, the authors conclude that the sample is a part of the population taken.

Saturated sampling is a sample that represents the population. It is usually done if the population is considered small or less than 100. In a study determining the population is very important, with the aim to facilitate and facilitate a study to be carried out. This research was carried out at SMK Negeri Kalibaru. The number of teachers and staff in Kalibaru Vocational School there are civil servants and nonpermanent teachers (GTT) and nonpermanent employees (PTT). The population in this study were all civil servant teachers of SMK Negeri Kalibaru Banyuwangi with 38 people as respondents in this study. The sampling technique is a census sample meaning that all populations are used as samples.

In this study using 3 variables, namely Motivation, Leadership and Performance. The independent variable or the independent variable is Motivation and Leadership. The dependent variable or the dependent variable is Performance. Based on the identification of variables, the following will be explained the operational definition of research variables namely Motivation ( $\left.\mathrm{X}^{1}\right)$, According to Porter et al., Filak \& Sheldon (Rasheed et al, 2010), teacher work motivation is very important for the performance and success of each education system. teacher work is an 
encouragement that moves and influences the teacher to carry out their duties and responsibilities properly in accordance with the stated goals.According to Cave and Mulloy (Schieb and Karabenick, 2011), teachers who have high work motivation will always develop their professionalism and innovative programs to improve student learning. Thus it can be concluded that teacher work motivation is a work motivation for teachers to carry out their duties and responsibilities as well as possible in order to achieve the goals that have been determined. According to Yunus (2007), the factors that influence individual work motivation and are indicators of motivation variables are maybe as they expected, b) Opportunity to advance, that is the possibility of advancing, advancing, gaining position and expertise; c) Type of work, i.e. there are jobs in accordance with educational background, experience, talents, and interests; d) The good name of the place of work, namely the company (school) that gives employees pride when working at the company or school; e) Colleagues, i.e. colleagues who are of the same understanding and suitable for cooperation; f) Wages, i.e. income received; g) Supervisors, namely leaders or superiors who have good relations with their subordinates, and consider the opinions expressed by their subordinates; h) Working hours, i.e. regular or certain hours of work in a day; i) Working conditions, such as workplace cleanliness, temperature, work space, ventilation, noise, odors, and so on.Variable Leadership $\left(\mathrm{X}^{2}\right)$, Hersey and Blanchard argues: "Leadership is the process of influencing the activity of a person or group to achieve goals in certain situations". Indicators in leadership are 1). Having the ability to surpass others. 2). Have a great sense of responsibility. 3). Want to work hard. 4). Jaunty. 5). Give examples of working with enthusiasm to subordinates. 6). Have a sense of integrity. The dependent variable in this study is Performance $\left(\mathrm{Y}^{2}\right)$ Performance is the work that can be achieved by a person or group of people in an organization in accordance with their respective authorities and responsibilities in an effort to achieve organizational goals legally, does not violate the law and does not conflict with morals or ethics. The indicators used in performance use the assessment of Buchori Zainudin (1982; 62), namely: 1). Harmonious relationship, 2). Job satisfaction 3). Work climate, 3). Usefulness. 4). Satisfaction in reward. Data collection methods in this research were carried out using questionnaires, interviews and literature study.

Data analysis methods include validity and reliability tests, econometric evaluations or classic assumption tests (normality tests, multicollinearity tests and heteroscedasticity tests), model suitability tests and multiple regression analysis.

\section{RESULT ANALYSIS}

This research obtained data through a questionnaire technique. Respondents were asked to express their opinions on questions raised by choosing one alternative answer from the 5 (five) answers available. Researchers distributed questionnaires within a period of 1 week. From the results of research conducted on 38 respondents as research objects, obtained several general characteristics of respondents including gender, age, years of service and salary.

Regression results obtained were having a normal or near normal distribution. To test the normality of data distribution in this study using the Kolmogorove-Smirnov normality test as shown in: 
Table 1. : One-Sample Kolmogorov-Smirnov Test

\begin{tabular}{|ll|r|r|r|}
\hline & & Motivasi & Kepemimpinan & Kinerja \\
\hline N & & 38 & 38 & 38 \\
Normal Parameters & & & \\
& Mean & 40,89 & 28,00 & 16,87 \\
& Std. Deviation & 3,117 & 1,903 & 1,492 \\
& Absolute &, 183 &, 253 &, 325 \\
Most Extreme Differences & Positive &, 131 &, 147 &, 325 \\
& Negative &,- 183 &,- 253 &,- 201 \\
Kolmogorov-Smirnov Z & & 1,125 & 1,560 & 2,004 \\
Asymp. Sig. (2-tailed) & &, 159 &, 215 &, 311 \\
\hline
\end{tabular}

Based on Table 1. above, the distribution of data in the motivational variable is significant 0.159 because it is greater than 0.05 , then the data distribution is normal, for data distribution in the leadership variable is significant 0.215

Table 2 : Coefficients

\section{coefficients ${ }^{a}$}

\begin{tabular}{|ll|r|r|}
\hline \multirow{2}{*}{ Model } & \multicolumn{2}{|c|}{ Collinearity Statistics } \\
\cline { 3 - 4 } & & Tolerance & VIF \\
\hline 1 & Motivasi & .515 & 1,940 \\
& Kepemimpinan & .645 & 1,550 \\
& Perilaku_Produktif & .625 & 1,601 \\
\hline
\end{tabular}

a. Dependent Variable: Kinerja because it is greater than 0.05 then the data distribution is normal, the data distribution in the significant performance variable is 0.311 because greater than 0.05 then the data distribution is normal.
From Table 2 above, the VIF value obtained for each variable is the motivation variable (X1) of 1,940, the leadership variable (X2) of 1,550. It is said that multicollinearity is free if the value of Variance Inflating Factor (VUF) is less than 10 or the correlation coefficient between independent variables is below 0.9 (Santoso, 2000). To find out the relationship between variables using correlation analysis and the following output is obtained:

Table 3. : Correlations

\begin{tabular}{|c|c|c|c|c|c|}
\hline \multicolumn{6}{|c|}{ Correlations } \\
\hline & & Motivasi & $\begin{array}{c}\text { Kepemimpina } \\
n\end{array}$ & $\begin{array}{c}\text { Perilaku_Prod } \\
\text { uktif }\end{array}$ & Kinerja \\
\hline \multirow{3}{*}{ Motivasi } & Pearson Correlation & 1 & $.583^{\prime \prime}$ & .601 &, 351 \\
\hline & Sig. (2-tailed) & &, 000 &, 000 &, 030 \\
\hline & $\mathrm{N}$ & 38 & 38 & 38 & 38 \\
\hline \multirow[t]{3}{*}{ Kepemimpinan } & Pearson Correlation & $.583^{11}$ & 1 &, $448^{113}$ & 038 \\
\hline & Sig. (2-tailed) &, 000 & &, 005 &, 820 \\
\hline & $\mathrm{N}$ & 38 & 38 & 38 & 38 \\
\hline \multirow[t]{3}{*}{ Perilaku_Produktif } & Pearson Correlation & $6011^{\prime \prime \prime}$ &, $448^{\prime \prime}$ & 1 & $.462^{m \prime}$ \\
\hline & Sig. (2-tailed) &, 000 &, 005 & &, 004 \\
\hline & $\mathrm{N}$ & 38 & 38 & 38 & 38 \\
\hline \multirow[t]{3}{*}{ Kinerja } & Pearson Correlation & $351^{\prime}$ &, 038 &, $462^{\mathrm{NI}}$ & 1 \\
\hline & Sig. (2-tailed) &, 030 & .820 &, 004 & \\
\hline & $\mathrm{N}$ & 38 & 38 & 38 & 38 \\
\hline
\end{tabular}


From the table above the performance variable also shows a significant relationship with the motivation variable (0.030). Performance variables also show a significant relationship with leadership (0.820).

Table 4.: Model Summary

Model Summary ${ }^{\text {b }}$

\begin{tabular}{|l|r|r|r|r|}
\hline Model & R & R Square & $\begin{array}{c}\text { Adjusted R } \\
\text { Square }\end{array}$ & $\begin{array}{c}\text { Std. Error of } \\
\text { the Estimate }\end{array}$ \\
\hline 1 &, $536^{\mathrm{a}}$ &, 287 &, 224 & 1,314 \\
\hline
\end{tabular}

a. Predictors: (Constant), Perilaku_Produktif, Kepemimpinan, Motivasi

\section{b. Dependent Variable: Kinerja}

In Table 4 model summary as shown above, the value of determination (Adjusted $\mathrm{R}$ Square) is 0.224 or $22.4 \%$. This value shows the magnitude of the influence of the motivation, leadership, variables on performance by $22.4 \%$. This means that the influence of other variables (e2) is $100 \%$ $22.4 \%=77.6 \%$.

Table 5. : Coefficients

Coefficients $^{\mathrm{a}}$

\begin{tabular}{|c|c|c|c|c|c|c|}
\hline \multirow[b]{2}{*}{ Mode } & & \multicolumn{2}{|c|}{ Unstandardized Coefficients } & \multirow{2}{*}{$\begin{array}{c}\begin{array}{c}\text { Standardized } \\
\text { Coefficients }\end{array} \\
\text { Beta } \\
\end{array}$} & \multirow[b]{2}{*}{$t$} & \multirow[b]{2}{*}{ Sig. } \\
\hline & & B & Std. Error & & & \\
\hline \multirow[t]{4}{*}{1} & (Constant) & 10,849 & 3,488 & & 3,110 &, 004 \\
\hline & Motivasi &, 130 &, 097 &, 272 & 1,348 & , 187 \\
\hline & Kepemimpinan & -249 &, 141 &,- 318 & $-1,762$ &, 087 \\
\hline & Perilaku_Produktif & 292 &, 121 & 441 & 2,406 &, 022 \\
\hline
\end{tabular}

a. Dependent Variable: Kinerja

Table 5. The coefficients above show the magnitude of the influence of motivation and leadership variables on the performance of 0.515 and 0.147 , respectively. The effect of motivation variables on performance is significant, because the probability (sig) is smaller than $\alpha(0.05)$ that is 0.003 , and the influence of the leadership variable on performance is not significant because the probability (sig) of leadership is 0.377 greater than $\alpha(0.05)$.

Motivation variable gives effect to the Performance variable of 0.272 . While the Leadership Variable gives effect to the Performance variable of -0.318 . So the hypothesis is:

\section{INTERPRETATION}

Motivation has a strategic role in performance. The results of data analysis in this study indicate that the existence of motivation has a significant effect on performance. This is indicated by correlations data in SPSS that the effect of motivation variables on performance is significant, because the probability (sig) is smaller, so motivation has a significant effect on the performance of PNS teachers in SMK NegeriKalibaru. According to Porter et al., Filak\& Sheldon (Rasheed et al, 2010), teacher work motivation is very important for the performance and success of any education system. According to 
SuryaniDewiPratiwi's research (2013) that Motivation influences teacher performance and Principal Leadership according to teacher perceptions influences teacher performance. According to research conducted by Raden Rudi Alhempi (2012). This study aims to determine job satisfaction is influenced by leadership, compensation and motivation. Motivation is a variable that influences job satisfaction. From several theories and previous research the results of this study are in accordance. But there are studies that say that motivation does not affect performance. Research conducted by YuliSuwati (2013) is partially that motivation is not affected on employee performance.

Leadership has a strategic role in performance. This study shows that leadership has a significant effect on performance. This is indicated by data correlations in SPSS that the influence of leadership variables on performance is not significant because of the probability (sig). Meanwhile, according to the Coefficients data from SPSS that the leadership variable has no significant effect on performance because the probability (sig) is greater than $\alpha$. Thus that leadership influences the performance of PNS teachers in Kalibaru State Vocational School. If the principal has good leadership will be able to improve teacher performance. Research conducted by SuryaniDewiPratiwi (2013), aims to find out motivation influences teacher performance. Teacher job satisfaction affects teacher performance Principal leadership according to teacher perceptions affect teacher performance. Research conducted by Marsuhi (2016) aims to determine the effect of leadership, discipline and motivation on the performance of Lumajang Police Station Sabhara members. Simultaneously Leadership, Discipline and Motivation greatly affect performance. According to Terrya and Frankin's theory (Amirullah, 2015)) that leadership with a relationship where a person (leader) influences others to want to work together to carry out tasks that are interrelated in order to achieve the desired goals of leaders and or groups. From several previous studies and theories about leadership, this research is very supportive.

\section{CONCLUSIONS}

Based on the results of research and a description of the Strategic Role of Motivation, Leadership to the performance of civil servant teachers in SMK Kalibaru, according to each hypothesis it can be concluded that: Motivation has a strategic role in improving Teacher Performance and Leadership in improving Teacher Performance has a strategic role as well. To further improve performance and be able to provide positive behavior towards Government Teachers, there needs to be innovation, creativity and good communication so there is a need for other factors or other variables. Researchers who are interested in conducting similar research in order to provide results that are different from the results of this study. This research is only limited to certain variables, namely motivation, leadership as an independent variable, and performance as a dependent variable. It is hoped that schools and principals will improve services in the form of adequate learning equipment and adequate infrastructure for Govenment teachers.

\section{REFERENCES}

Amirullah, 2015, Pengantar Manajemen, MitraWacana Media, Jakarta.

Agung Prihantoro, 2012, Pengaruh Motivasi, Disiplin, Lingkungan Kerja melalui Komitmen terhadap Kinerja Sumber Daya Manusia, Jurnal Value Added, Vol.8,No 2, Maret 2012-Agustus 2012

Azwar, Saifuddin, 2010. Reliabilitas dan Validitas, Pustaka Belajar, Yogyakarta.

Dharma, Agus, 2003. Manajemen supervisi, Raja Grafindo Persada, Jakarta. 
Ghozali, Imam, 2005. Aplikasi analisis Multivariate dengan Program SPSS. Badan Penerbit Universitas Diponegoro.

Hariandja Marihot Tua, Efendi, 2007. Manajemen Sumber Daya Manusia, Penerbit Grasindo, Jakarta.

Hasibuan, Malayu S.P, 2009. Manajemen Sumber Daya Manusia, Edisi Revisi, Bumi Aksara, Jakarta.

Hisbullah Muhib, 2017, Pengaruh Motivasi, Reward dan Lingkungan Kerja terhadap Komitmen serta Dampaknya pada Kinerja,Tesis STIE Mandala Jember.

Istijanto, M. 2010. Riset Sumber Daya Manusia. Jakarta: PT Gramedia Pustaka Utama

Kuncoro, Mudrajat. 2007. Metode Kwantitatif. Yogyakarta : Unit Penerbitan dan Percetakan (UPP) STIP KYPN.

Lako, Adreas. 2004. Kepemimpinan dan kinerja Organisasi : Isu, Teori, dan Solusi. Cetakan Pertama. Penerbit Amara Books, Yogyakarta.

Mangkunegara, Anwar, Prabu. 2009. Evaluasi Kinerja Sumber daya Manusia, PT. Rineka Aditama, Bandung.

Marsuhin,

$$
\text { (2016), Pengaruh }
$$

Kepemimpinan, Kedisiplinan dan Motivasi terhadap kinerja,Tesis STIE Mandala Jember.

Ni Made Oktaviani ,Ayu Desi Indrawati, 2014, Pengaruh Gaya Kepemimpinan,Kompensasi Finansial pada Kepuasan Kerja dan
Kinerja Karyawan di CV. Wali Sukses Mandiri, Fakultas Ekonomi dan Bisnis Universitas Udayana.

P. Siagian, Sondang, 2004. Teori Motivasi dan Aplikasinya, Rineka Cipta, Jakarta.

Raden Rudi Alhempi ,2012.Pengaruh Kepemimpinan, Kometmen, Motivasi terhadap Kepuasan Kerja, Jurnal Media Riset Bisnis \& manajemen, Vo.12, No. 1, April 2012, pp. 58-80.

Riduwan, 2005. Dasar-Dasar Statistika, CV. Alfabeta, Bandung.

Robbins, Stephen. 2001. Perilaku Organisasi. Jakarta: PT. Prehellindo.

Sugiyono, 2007. Statistika untuk Penelitian, CV. Alfabeta, Bandung.

SuryaniDewiPratiwi ( 2013 ), Pengaruh Motivasi, KepuasanKerja, dan Kepemimpinan, menuruttpersepsi guru terhadap kinerja guru, Jurnal Pendidikan Insan Mandiri: Vol.1, No.1 (2013)

Wibowo. 2012. Manajemen Kerja. Yogyakarta. Edisi Ketiga. Jakarta: PT Raja Garafindo Persada

Widagdo, 2017. Manajemen Sumber Daya Manusia, Mandala Press, Jember.

Yuli Suwati , (2013), Pengaruh Kompensasi dan Motivasi Kerja terhadap Kinerja Karyawan Pada PT. Tunas Hijau Samarinda, Journal Ilmu Administrasi Bisnis, Volume 1, nomor 1, 2013:41-55 